The use of mirrors as condensers

This content has been downloaded from IOPscience. Please scroll down to see the full text. 1911 Trans. Opt. Soc. 1363

(http://iopscience.iop.org/1475-4878/13/1/309)

View the table of contents for this issue, or go to the journal homepage for more

Download details:

IP Address: 139.184.14.159

This content was downloaded on 02/10/2015 at 02:37

Please note that terms and conditions apply. 


\title{
THE USE OF MIRRORS AS CONDENSERS.
}

\author{
BY S. D. Chalmers, M.A.
}

November 14th, 1912.

The purpose of this note is to call attention to the convenience of using mirrors rather than lenses as condensers for spectrographs and optical testing apparatus.

In the first place the mirror is free from chromatic aberration, and if the source be placed at a distance nearly equal to the radius of curvature there is little or no spherical aberration or coma. The astigmatism which is present is rather useful than otherwise, since a line image is formed of the point source, and by changing the angle of incidence the length of the focal line may be modified as desired.

It is essential that the mirror should be so mounted that it turns about a line on the optical axis of the system.

The convenience of using different sources by merely rotating the mirror is very great. For use with ultra-violet light the mirror should be of speculum metal or nickel on glass. 